\title{
Development, amino acid utilization and cell allocation in bovine embryos after in vitro production in contrasting culture systems
}

\author{
M. Kuran ${ }^{1 *}$, J. J. Robinson ${ }^{1}$, D. S. Brown ${ }^{2}$ and T. G. McEvoy ${ }^{1}$ \\ ${ }^{1}$ Scottish Agricultural College, Craibstone Estate, Bucksburn, Aberdeen AB21 9YA, UK; and \\ ${ }^{2}$ Rowett Research Institute, Bucksburn, Aberdeen, AB21 9SB, UK
}

The effects of protein-supplemented and protein-free media on amino acid uptake, protein synthesis and cell differentiation in bovine blastocysts were investigated. Four formulations of synthetic oviduct fluid were used. Each formulation was identified by the principal supplement: bovine serum albumin $(0.4 \%, \mathrm{w} / \mathrm{v})$; polyvinyl alcohol $(0.3 \%, w / v)$; or either of two steer sera $(10 \%, v / v)$. After zygote culture, blastocyst yields (day 7.5) were lowest in protein-free medium and highest in albuminsupplemented medium. Subsequent $12 \mathrm{~h}$ incubation in the presence of both essential and non-essential amino acids was used for the measurement of amino acid flux. All blastocysts released alanine but consumed aspartate $(P<0.001)$ and the extent was influenced by prior culture conditions. Aspartate uptake was lower in blastocysts produced in protein-free conditions $(P<0.05)$ than in blastocysts produced in albumin-supplemented conditions. Consumption indices for 16 other amino acids were not influenced by blastocyst source. Cell counts and hatching incidences were highest for albuminsupplemented blastocysts, but were similar among blastocysts from the protein-free and serum-dependent treatments. Crucially, the use of protein-free medium for zygote culture did not compromise resultant blastocysts in terms of either de novo protein synthesis $\left(\left[{ }^{3} \mathrm{H}\right]\right.$ phenylalanine incorporation) or trophectoderm function (phenotype based on interferon-tau detection). Thus, although blastocyst yields were compromised after zygote culture in a protein-free (vis-à-vis albumin-supplemented) medium, amino acid flux was qualitatively conserved, and only quantitatively modified in the case of alanine and aspartate. Moreover, vital properties of blastocysts that were produced, including de novo protein synthesis and trophectodermal cell function, apparently were not adversely affected by protein deprivation.

\section{Introduction}

Two major considerations governing choice of culture system for in vitro production of bovine and other mammalian embryos are the efficiency of blastocyst production and the developmental competence of those blastocyts produced. The efficiency of blastocyst production is readily quantified, but it is more difficult to determine the developmental capabilities of individual blastocysts, either in terms of current functional competence or generation of viable offspring. Although production of healthy offspring is the ultimate indicator of developmental capacity - and failure in this regard is one reason for seeking alternatives to serumdependent cultures (Leese et al., 1998; Gardner, 1999; McEvoy et al., 2000a) - integrity of embryos at the blastocyst stage is crucial too. Studies of bovine and ovine embryos produced in vitro have demonstrated that they differ from embryos produced in vivo in morphology, metabolism and gene expression (Wrenzycki et al., 1996; Thompson, 1997; Holm and Callesen, 1998; Abe et al.,

*Correspondence: Ondokuz Mayis Universitesi, Ziraat Fakultesi, Kurupelit, 55139 Samsun, Turkey

Email: mkuran@samsun.omu.edu.tr 1999a; Niemann and Wrenzycki, 2000). In addition, there is evidence that choice of culture conditions and constituents can affect embryo morphology (Abe et al., 1999b), carbohydrate metabolism (Rieger et al., 1995; Eckert et al., 1998; Krisher et al., 1999), apoptosis (Byrne et al., 1999) and, in both the short and longer term, expression of developmentally important genes (Natale et al., 1998; Wrenzycki et al., 1999, 2001; Young et al., 2001).

Significant advances have been made towards a comprehensive understanding of bovine embryo needs and preferences in terms of energy substrate use. In contrast, progress towards quantifying the extent to which amino acids are either needed or metabolized in various culture environments has been limited (Thompson, 2000). Until recently, this was of little consequence for commercial embryo production because, whenever amino acids were added to media, most formulations also included proteins, which, via endocytosis, could augment amino acid supplies to the embryo (Pemble and Kaye, 1976; Thompson et al., 1998). However, the need for more precision has arisen because of interest in protein-free media (McEvoy et al., 2000a), which would avoid the biohazards associated with serum and albumin (Guerin et al., 1997), particularly in the UK and other countries where these products are not pathogen-free. 
Opinion is divided on the question of whether protein provision is an obligatory requirement for optimal bovine embryo production in vitro. Protein-free media can support zygote development to the blastocyst stage, but have yet to emulate conventional formulations in terms of blastocyst production. Nevertheless, zygotes cultured in chemically defined media in the absence of protein have generated blastocysts, which have subsequently developed in vivo to produce healthy calves (Keskintepe et al., 1995; Holm et al., 1999; Hernandez-Fonseca et al., 2002). Most success with defined media has derived from an appreciation that, when protein is excluded, there is a need for formulations that take account of the fact that in addition to a macromolecular substitute, such as polyvinyl alcohol or hyaluronic acid, contaminants normally present in albumin or serum must be provided (Kuran et al., 2001).

It has been shown that protein content (Thompson et al., 1998), but not protein synthesis (Thompson et al., 1998; Kuran et al., 2001), is compromised in embryos produced in protein-free media; however, whether this compromise is detrimental remains uncertain. McEvoy and Sreenan (1990) demonstrated that demi-embryos can generate healthy calves, indicating that protein mass per se is less crucial for development and survival of blastocysts after culture than the capacity of the blastocyst to synthesize protein de novo. Consequently, amino acid availability, flux and utilization will be key determinants of the capacity of the embryo to develop and survive after culture. Partridge and Leese (1996) and Jung et al. (1998) have reported amino acid consumption at various preimplantation stages after production in albumin-supplemented synthetic oviduct fluid (SOF) medium. Using a similar strategy, Lee and Fukui (1996) reported amino acid uptake by morulae and blastocysts produced via two-stage culture, using a protein-free formulation up to $30 \mathrm{~h}$ after fertilization, with the addition of bovine serum albumin thereafter. Analogous investigations would help to determine the impact of contrasting in vitro production environments on amino acid uptake by bovine embryos. However, such work to our knowledge has not yet been reported.

A prerequisite for survival of bovine blastocysts after culture in vitro is the ability to generate a trophectodermderived protein signal (interferon tau, IFN- $\tau$ ), which is crucial for establishment of pregnancy. Each blastocyst must be capable of efficient de novo protein synthesis and have an adequate complement of differentiated trophectoderm cells. Consequently, any in vitro production system that compromises these features cannot be considered suitable, irrespective of whether the culture medium includes proteins, such as serum and albumin.

The present study investigated amino acid flux (uptake or release), de novo protein synthesis and allocation of cells to inner cell mass (ICM) and trophectoderm (TE) in blastocysts produced in a protein-free medium and compared the results with those for embryos produced in either albuminor serum-supplemented systems, to determine the impact of contrasting media formulations on bovine embryo produc- tion and viability. Two sera were used, which were each processed in standard conditions but with different concentrations of some key amino acids, notably glycine and serine, to resolve whether exogenous protein composition is likely to influence amino acid consumption profiles. Preliminary results for some of this work have been reported (Kuran et al., 1999; McEvoy et al., 2000b).

\section{Materials and Methods}

All reagents and media were from Sigma Chemical Co. (Dorset, UK) unless otherwise stated.

\section{In vitro maturation and fertilization}

Ovaries were collected from beef heifers at slaughter and transported to the laboratory at approximately $35^{\circ} \mathrm{C}$ in PBS (Oxoid, Basingstoke) containing $0.05 \mathrm{~g}$ kanamycin sulphate $\mathrm{I}^{-1}$. Cumulus-oocyte complexes were recovered from follicles $2-8 \mathrm{~mm}$ in diameter by aspiration, using an $18 \mathrm{~g}$ needle and $5 \mathrm{ml}$ syringe, and were collected in 2-3 $\mathrm{ml}$ of Hepes-buffered Medium 199 containing Earle's salts and supplemented with 10\% (v/v) steer serum (Globepharm, Surrey) and antibiotics (50000 iu penicillin $\mathrm{I}^{-1}$ and $50 \mathrm{mg}$ streptomycin sulphate $\left.\left.\right|^{-1}\right)$. The morphology of the cumulus-oocyte complexes was assessed before maturation and only oocytes with compact, non-atretic cumulus investment and evenly granulated cytoplasm were selected for maturation. The maturation medium used was bicarbonate-buffered Medium 199 with Earle's salts (Life Technologies, Paisley) supplemented with $10 \%$ (v/v) steer serum and antibiotics (50 000 iu penicillin $\mathrm{I}^{-1}$ and $50 \mathrm{mg}$ streptomycin sulphate $\left.\mathrm{I}^{-1}\right)$. After washing twice in this medium, selected cumulus-oocyte complexes were matured in $30 \mathrm{~mm}$ diameter culture dishes $(3 \mathrm{ml}$ medium per dish) for $24 \mathrm{~h}$ at $38.5^{\circ} \mathrm{C}$ in a humidified atmosphere of $5 \% \mathrm{CO}_{2}$ in air.

Frozen-thawed motile spermatozoa from a single bull were used for in vitro fertilization at $1 \times 10^{6}$ motile spermatozoa $\mathrm{ml}^{-1}$ of fertilization medium following a standard swim-up procedure (Parrish et al., 1986) in $1 \mathrm{ml}$ of a modified calcium-free Tyrode's albumin lactate pyruvate (TALP) capacitation medium containing $0.6 \%$ (w/v) BSA (fraction V), 50000 iu penicillin $\mathrm{I}^{-1}$ and $50 \mathrm{mg}$ streptomycin sulphate $\mathrm{I}^{-1}(\mathrm{pH}$ 7.4). Fertilization medium was modified TALP (Lu et al., 1987) supplemented with $0.2 \mu \mathrm{mol}$ penicillamine $\mathrm{I}^{-1}, 0.1 \mu \mathrm{mol}$ hypotaurine $\mathrm{I}^{-1}, 0.02 \mu \mathrm{mol}$ adrenaline $\mathrm{I}^{-1}, 0.6 \%(\mathrm{w} / \mathrm{v})$ fatty acid-free BSA, $30 \mathrm{mg}$ heparin $\mathrm{I}^{-1}, 50000$ iu penicillin $\mathrm{I}^{-1}$ and $50 \mathrm{mg}$ streptomycin sulphate $\mathrm{I}^{-1}$ ( $\mathrm{pH}$ 7.8). After maturation, most of the cumulus cells were removed by gentle pipetting before the oocytes were washed twice in Hepes-buffered TALP supplemented with $0.3 \%(\mathrm{w} / \mathrm{v})$ BSA (fraction V), 50000 iu penicillin $\mathrm{I}^{-1}$ and $50 \mathrm{mg}$ streptomycin sulphate $\mathrm{I}^{-1}$. Matured oocytes (15-20 ova per drop) were placed in the fertilization medium droplets (50 $\mu$ l final volume) in which oocytes and spermatozoa were co-incubated under mineral oil for $22 \mathrm{~h}$ at $38.5^{\circ} \mathrm{C}$ in a humidified atmosphere of $5 \% \mathrm{CO}_{2}$ in air. 
In vitro culture

After insemination, putative zygotes were removed and washed twice in a Hepes-buffered modification of SOF medium (Tervit et al., 1972). Randomly selected groups of ten zygotes were placed in $20 \mu \mathrm{l}$ microdrops of one of four media formulations and cultured in $5 \% \mathrm{CO}_{2}, 5 \% \mathrm{O}_{2}$ and $90 \% \mathrm{~N}_{2}$ at $38.5^{\circ} \mathrm{C}$ in ten replicates. All droplets were renewed every $48 \mathrm{~h}$. All four media formulations were derivatives of a basal bicarbonate-buffered SOF medium (Kuran et al., 2001). The supplements added to complete the different formulations were: (i) $10.0 \%(\mathrm{v} / \mathrm{v})$ steer serum $\mathrm{A}$ (SSA); (ii) $10.0 \%$ (v/v) steer serum B (SSB); (iii) $0.4 \%(\mathrm{w} / \mathrm{v})$ fatty acid-free bovine serum albumin (BSA) plus $2.0 \%(\mathrm{v} / \mathrm{v})$ basal medium eagle (BME) essential amino acids (EAA; $\times 50)$ and $1.0 \%(\mathrm{v} / \mathrm{v})$ minimum essential medium (MEM) non-essential amino acids (NEAA; $\times 100)($ SBSA); and (iv) $0.3 \%(\mathrm{w} / \mathrm{v})$ polyvinyl alcohol (PVA) plus $0.5 \mathrm{mmol}$ sodium citrate $\mathrm{I}^{-1}$ plus $5 \mu \mathrm{g}$ epidermal growth factor (EGF; tissue culture grade) $\mathrm{I}^{-1}$ plus $1 \%(\mathrm{v} / \mathrm{v})$ NEAA (SPVA). L-glutamine $\left(1 \mathrm{mmol} \mathrm{I}^{-1}\right)$ was present in all four formulations. The sera used (Table 1) were from steers fed for 10 days on a diet with either a high (190 g dry matter $\mathrm{kg}^{-1}$; serum A donors) or low (120 g dry matter kg-1; serum B donors) protein content. When used as culture supplements in vitro, these differed $(\mathrm{A}>\mathrm{B})$ in their capacity to increase ammonia concentrations (Carolan et al., 1997). Moreover, ovine embryos produced in the presence of one of these sera have shown features characteristic of the large offspring syndrome (Sinclair et al., 1999). Zygotes assigned to SPVA were washed in gas-equilibrated SPVA medium ten times before introduction to the culture drops. On day 3 of development (day $0=$ in vitro fertilization), cleavage rate was recorded and cleaved zygotes were cultured in groups of four per $20 \mu \mathrm{l}$ drop until day 7. At day 7, blastocyst yields, quality grades (Lindner and Wright, 1983) and precise developmental stages were recorded.

\section{Assay of amino acid flux in blastocysts from different culture environments}

Blastocysts produced in SSA, SSB, SBSA and SPVA systems were washed in SOF supplemented with $0.1 \%(\mathrm{w} / \mathrm{v})$ PVA plus $2 \%(\mathrm{v} / \mathrm{v})$ BME EAA $(\times 50)$ and $1 \%(\mathrm{v} / \mathrm{v}) \mathrm{MEM}$ NEAA $(\times 100)$. Between 6 and 16 blastocysts per $20 \mu \mathrm{l}$ droplet were incubated in the same medium for $1 \mathrm{~h}$ in a humidified atmosphere of $5 \% \mathrm{CO}_{2}, 5 \% \mathrm{O}_{2}$ and $90 \% \mathrm{~N}_{2}$ to allow them to equilibrate. Blastocysts were then transferred to $20 \mu \mathrm{l}$ of fresh 'test' droplets of this same medium and incubated for $12 \mathrm{~h}$ (day 7.5 to day 8.0) in the same environment. Droplets without embryos were used as 'control' references. At the end of incubation, $10 \mu \mathrm{l}$ of medium was removed from each 'test' and 'control' droplet, and stored at $-20^{\circ} \mathrm{C}$ for amino acid analysis. Blastocysts were then used for determinations of de novo protein synthesis or to quantify the numbers of cells present. Individual amino acid concentrations in frozen-thawed incubation medium droplets were determined by reverse
Table 1. Amino acid, insulin-like growth factor I (IGF-I), urea, ammonia and lipid profiles of the steer sera used

\begin{tabular}{|c|c|c|}
\hline & Serum A & Serum B \\
\hline \multicolumn{3}{|l|}{ Amino acid (nmol g-1) } \\
\hline Alanine & 312.5 & 353.3 \\
\hline Anserine + tryptophan & 30.0 & 33.9 \\
\hline Arginine & 160.9 & 138.1 \\
\hline Asparagine & 65.2 & 63.5 \\
\hline Aspartate & 5.2 & 7.4 \\
\hline$\alpha$-amino $n$-butyric acid & 9.1 & 11.1 \\
\hline Carnosine & 12.5 & 26.1 \\
\hline Citrulline & 89.1 & 84.3 \\
\hline Glutamate & 145.4 & 129.7 \\
\hline Glutamine & 217.7 & 150.2 \\
\hline Glycine & 300.0 & 361.5 \\
\hline Histidine & 66.3 & 70.8 \\
\hline 1-methyl histidine & 7.5 & 13.9 \\
\hline 3-methyl histidine & 4.0 & 4.6 \\
\hline Isoleucine & 88.8 & 109.4 \\
\hline Leucine & 143.1 & 156.7 \\
\hline Lysine & 121.6 & 146.7 \\
\hline Methionine & 19.4 & 21.7 \\
\hline Ornithine & 109.5 & 128.6 \\
\hline Phenylalanine & 55.4 & 64.7 \\
\hline Phosphoserine & 9.3 & 20.6 \\
\hline Proline & 86.6 & 101.4 \\
\hline Serine & 123.8 & 166.5 \\
\hline Taurine & 77.8 & 61.8 \\
\hline Threonine & 75.1 & 97.5 \\
\hline Tyrosine & 52.9 & 55.0 \\
\hline Valine & 198.6 & 231.4 \\
\hline IGF-I $\left(\mu \mathrm{g}^{-1}\right)$ & 553.8 & 398.6 \\
\hline Urea $\left(\mathrm{nmol} \mathrm{g}^{-1}\right)$ & 6693.5 & 3472.1 \\
\hline Ammonia $\left(\mu \mathrm{mol} \mathrm{I}^{-1}\right)$ & 509.5 & 296.8 \\
\hline \multicolumn{3}{|l|}{ Lipid ( $\left.\mu \mathrm{mol} \mathrm{I}^{-1}\right)$} \\
\hline HDL-Cholesterol & 0.71 & 0.57 \\
\hline LDL-Cholesterol & 0.61 & 0.51 \\
\hline Total cholesterol & 1.09 & 0.34 \\
\hline Triglycerides & 2.94 & 2.23 \\
\hline
\end{tabular}

HDL: high density lipids; LDL: low density lipids.

phase HPLC (Waters Pico Tag Amino Acid Analyser) after derivatization of the samples using phenylisothiocyanate (Heinrikson and Meredith, 1984). For 18 amino acids, indices of depletion from, or release into, the incubation medium by blastocysts were measured as the difference in amino acid concentrations between 'test' and 'control' samples. Cysteine and tryptophan concentrations were not assayed.

\section{Differential staining of ICM and TE cells}

After the amino acid metabolism studies, expanded blastocysts (replicates one to four, inclusive) were subjected to zona pellucida removal by the method of Van Soom et al. (1996). Briefly, embryos were washed in PBS and then, in 
groups of three to five, were exposed to prewarmed $\left(37^{\circ} \mathrm{C}\right)$ pronase solution $(0.5 \%$ protease) for approximately $5 \mathrm{~min}$ for SPVA embryos and for $1 \mathrm{~min}$ for all other embryos. The embryos were then transferred to prewarmed acid Tyrode solution ( $\mathrm{pH}$ 2.1) for either 2 min (SPVA embryos) or $1 \mathrm{~min}$ (other treatments), before being placed promptly in Hepesbuffered SOF. The TE and ICM cells of hatched and zona pellucida-free expanded blastocysts were subjected to immunosurgery using the method of Stojkovic et al. (1998). In this procedure, embryos were washed four times in prewarmed PBS and incubated in a 1:2 dilution of rabbit antiserum in PBS for $45 \mathrm{~min}$ at $39^{\circ} \mathrm{C}$ in a humidified atmosphere of $5 \% \mathrm{CO}_{2}$ in air. The rabbit antiserum was raised against a mixture of recombinant bovine IFN- $\tau$ and serum-containing medium conditioned by trophoblastic vesicles produced in vitro (Stojkovic et al., 1998). The embryos were then washed four times in prewarmed PBS and incubated in PBS supplemented with $5 \%(\mathrm{v} / \mathrm{v})$ guineapig complement and $50 \mathrm{mg}$ propidium iodide $\mathrm{I}^{-1}$ for $45 \mathrm{~min}$ at $39^{\circ} \mathrm{C}$ in a humidified atmosphere of $5 \% \mathrm{CO}_{2}$ in air. This procedure resulted in selective antibody-mediated complement lysis of trophectoderm cells and staining of trophectoderm cell nuclei. Subsequently, embryos were washed in PBS and placed in cold absolute ethanol containing $25 \mathrm{mg}$ bisbenzimide (Hoechst 33342) $\mathrm{I}^{-1}$ for $30 \mathrm{~min}$ at $4^{\circ} \mathrm{C}$. This procedure resulted in the staining of all cell nuclei (inner cell mass and lysed trophectoderm) and the fixation of the embryo. Embryos were subsequently washed in absolute ethanol and mounted in a glycerol drop on a glass slide and covered with a coverslip. ICM and TE cells were counted using a fluorescence microscope.

\section{Total cell counts and blastocyst diameters}

Blastocysts (replicates five, nine and ten) retrieved from the amino acid flux assay droplets were washed twice in Hepes-buffered SOF and fixed in a solution of ethanol and acetic acid (volume ratio $=3: 1$ ) for a minimum of $24 \mathrm{~h}$. Subsequently, each blastocyst assigned to this process was placed on a glass slide, dried, stained with $15 \mu \mathrm{l}$ of $10 \mathrm{mg}$ bisbenzimide stain (Hoechst 33342) $\mathrm{I}^{-1}$ prepared in $2.3 \%$ $(\mathrm{w} / \mathrm{v})$ sodium citrate and gently overlaid with a coverslip, which was sealed along its edges with varnish. The total number of cells in each blastocyst was determined by counting stained nuclei with the aid of a fluorescence microscope.

\section{De novo protein synthesis}

Blastocysts (replicates six to eight) were washed four times in phosphate-buffered ovum culture medium (OCM; Imperial Laboratories, Andover) and incorporation of $\left[{ }^{3} \mathrm{H}\right]$ phenylalanine was determined, using the method described by McEvoy et al. (1997). Briefly, labelling of de novo synthesized protein was carried out in separate wells of 16-well dishes, with each well containing $15 \mu \mathrm{l}\left[{ }^{3} \mathrm{H}\right]$ phenylalanine solution; this comprised, in a 1:9 volume ratio, $10 \times$ Dulbecco's modified Eagle's medium (DMEM) and aqueous L-[2,6- $\left.{ }^{3} \mathrm{H}\right]$ phenylalanine $\left(37 \mathrm{MBq} \mathrm{ml}^{-1}\right.$, specific activity $2.07 \mathrm{TBq} \mathrm{m^{-1 }}$; Amersham International, Little Chalfont). The addition of individual embryos in $100 \mu \mathrm{l}$ OCM resulted in a total volume of $115 \mu \mathrm{l}$ per well, which was then incubated for $2 \mathrm{~h}$ at $38.5^{\circ} \mathrm{C}$. At the end of the incubation period, embryos were washed four times in ice-cold OCM, and each embryo was stored at $-80^{\circ} \mathrm{C}$ in $50 \mu \mathrm{l} \mathrm{OCM} \mathrm{until} \mathrm{processing.} \mathrm{The} \mathrm{processing} \mathrm{protocol}$ (McEvoy et al., 1995) involved dissolution in $50 \mu \mathrm{l}$ of $0.6 \mathrm{~mol} \mathrm{NaOH} \mathrm{I}{ }^{-1}$, protein precipitation in $30 \mu \mathrm{l}$ of $2.0 \mathrm{~mol}$ perchloric acid (PCA) $\mathrm{I}^{-1}$ and repeated washing with $100 \mu \mathrm{l}$ of $0.2 \mathrm{~mol} \mathrm{PCA} \mathrm{I}^{-1}$. The protein was redissolved in $100 \mu \mathrm{l}$ of $0.3 \mathrm{~mol} \mathrm{NaOH} \mathrm{I}{ }^{-1}$, and was added, together with $100 \mu \mathrm{l}$ of $0.5 \mathrm{~mol} \mathrm{HCl} \mathrm{I}^{-1}$ to prevent chemiluminescence, to a vial containing $5 \mathrm{ml}$ liquid scintillation counter cocktail (Emulsifier Safe; Canberra Packard, Pangbourne). The radioactivity of the samples, together with the appropriate controls, was determined in a $\beta$-counter and results, after correction for background values, were expressed as d.p.m.

\section{Statistical analysis}

Zygote cleavage, blastocyst production, hatching and 'ICM/total' cell data were analysed using Generalized Linear Model procedures for binomial data within the GENSTAT statistical package (Genstat 5, Version 4.1, 1998; Lawes Agricultural Trust, Rothamstead). The model, which facilitated pairwise comparisons, included 'replicate' and 'treatment'. Indices of de novo protein synthesis $\left(\left[{ }^{3} \mathrm{H}\right]\right.$ phenylalanine incorporation; $\log _{10}$ d.p.m. counts) were tested using an REML procedure (Genstat 5) with 'replicate' as the random factor and 'treatment', 'stage' and 'treatment $\times$ stage' as fixed factors. The same procedure was used for analysis of blastocyst diameter data, with 'treatment' or 'presence versus absence of protein' as fixed factors, and for analysis of cell counts ( $\log _{10}$-transformed data), with 'treatment' or 'presence versus absence of albumin' as fixed factors. When REML indicated significance, pairwise comparisons were carried out using Tukey's test based on SED values. Individual net depletion data for amino acids were tested for significance from zero by the Student's $t$ test, and treatment effects were compared using one-way ANOVA and Tukey's pairwise test. Results are presented as untransformed mean ( \pm SEM) values, except for d.p.m. values which are $\log _{10}$-transformed.

\section{Results}

\section{Embryo development in vitro}

The presence of serum compromised cleavage of zygotes in comparison with cleavage achieved in either SBSA or SPVA $(P<0.001$; Table 2), and there was no difference between SSA and SSB or between SBSA and SPVA. However, when expressed as a percentage of cleaved zygotes, the protein-free medium yielded fewer blastocysts on day 7 $(P<0.001)$ than any of the protein-supplemented formula- 


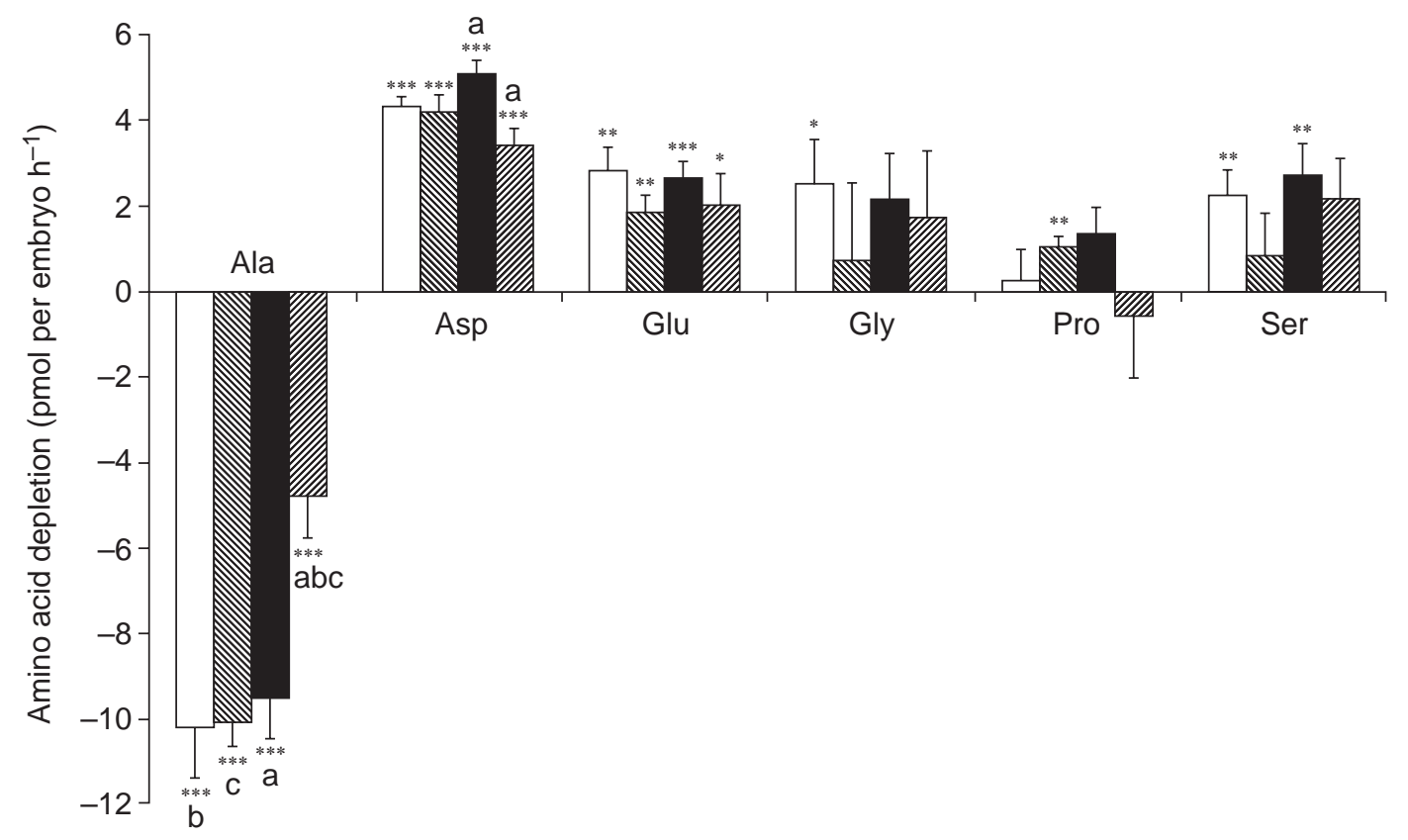

Fig. 1. Depletion of non-essential amino acids after $12 \mathrm{~h}$ of incubation (day 7.5 to day 8.0 ) of bovine blastocysts produced in vitro in the presence of serum (SSA, $\square$; SSB, $\mathbb{N}$ ) or albumin (SBSA, $\mathbf{\square})$ or in the absence of protein (SPVA, $\mathbb{Q}$ ) in protein-free 'test' medium (synthetic oviduct fluid, polyvinyl alcohol, essential amino acids and non-essential amino acids). Values are mean \pm SEM net depletion data $(n=8-10$ replicates) expressed in pmol per embryo $\mathrm{h}^{-1}$. Negative values denote net amino acid release from embryos. Differences from 'control' (embryo-free) droplet values are denoted by asterisks $\left({ }^{*} P<0.05, * * P<0.01,{ }^{* * *} P\right.$ $<0.001)$ whereas, for each amino acid, treatments with superscripts in common differ significantly $\left({ }^{a} P<\right.$ $\left.0.05,{ }^{b} P<0.01,{ }^{c} P<0.01\right)$.

tions, and SBSA yielded fewer blastocysts than each of the serum-supplemented cultures $(P<0.001)$. By day 8 , blastocyst production efficiency in the defined production system, in terms of both total and good quality blastocysts (grade 1: excellent; grade 2: very good), was no more than half that achieved in all other formulations $(P<0.001)$. In contrast, by day 8 , the efficiency of generating good quality blastocysts in SBSA cultures was not significantly different from that recorded in the presence of serum.

Of the total numbers of blastocysts produced in each treatment, the percentages classified as good quality (grades 1 and 2) were not significantly different. However, after culture in the absence of exogenous protein or in the presence of either serum, the incidence of blastocyst hatching was significantly lower $(P<0.01)$ than that achieved in the formulation that relied on albumin. The hatching outcomes in each of the serum-supplemented systems were contrary to intuitive expectations based on timing of initial blastocoel formation. Embryos cultured in the presence of serum tended to reach blastocyst stages earlier, with more than $70 \%$ of those forming a blastocyst having done so by early day 7 , compared with just 50 and $46 \%$ for SBSA and SPVA, respectively.

\section{Amino acid depletion by embryos from culture media}

Individual amino acid depletion indices (mean \pm SEM net values; pmol per embryo $\mathrm{h}^{-1}$ ) after $12 \mathrm{~h}$ incubation of blastocysts produced in the four distinct culture systems are presented (Figs 1 and 2; Table 3). Of the 18 amino acids that were studied, only alanine concentrations consistently increased in the culture media (that is, values differed significantly from 'control' readings), reflecting significant net release, denoted as negative depletion values, by blastocysts from all four culture systems $(P<0.001 ;$ Fig. 1$)$. In contrast, nine amino acids were taken up in significant amounts by blastocysts produced in SBSA compared with five, five and three amino acids by those produced in SSA, SSB and SPVA, respectively. Embryos from all four culture systems used took up significant amounts of aspartate $(P<0.001)$. Glutamate was also taken up by embryos from all treatments (SSA, $P<0.001$; SSB, $P<0.01$; SBSA, $P<0.001$; SPVA, $P<0.05)$, whereas arginine was depleted from 'test' medium by SBSA $(P<0.001)$, SSA $(P<0.001)$ and SSB $(P<0.01)$ embryos, but not by SPVA embryos. Embryos produced in SSA depleted both serine $(P<0.01)$ and glycine $(P<0.05)$, whereas those produced in SSB took 
up proline $(P<0.01)$ and isoleucine $(P<0.05)$. In addition to aspartate and glutamate, SBSA embryos took up serine $(P<0.01)$, histidine $(P<0.05)$, tyrosine $(P<0.05)$, methionine $(P<0.05)$, isoleucine $(P<0.05)$ and lysine $(P<0.05)$. Histidine $(P<0.01)$ was also taken up by embryos produced in SPVA.

SPVA embryos released less alanine than did blastocysts generated in the presence of either albumin $(P<0.05)$ or serum $(P<0.01)$ (Fig. 1$)$. Blastocysts produced in proteinfree conditions also depleted less aspartate than blastocysts generated in the presence of albumin $(P<0.05)$. Collectively, blastocysts from serum-free cultures (SBSA and SPVA) depleted more histidine than did blastocysts from serumsupplemented (SSA and SSB) cultures $(P<0.05)$. Analysis of mean ( \pm SEM) indices for net flux (depletion or release) of all other essential and non-essential amino acids indicated no other significant treatment effects. Mean ( \pm SEM) concentrations of six amino acids were not significantly altered by any treatment (Table 3).

\section{Blastocyst cell proliferation and differentiation}

ICM, TE and the total number of cells recorded for blastocysts from the different culture systems (replicates one to four, inclusive) are presented (Fig. 3). Blastocysts produced in the presence of albumin had more ICM cells $(P<0.05)$ than did those from serum-supplemented formulations. The same outcome applied for total number of cells. However, for blastocysts generated in the absence of protein, neither ICM nor total number of cells differed from any protein-inclusive treatment. The number of trophectoderm cells did not differ significantly among treatments. The proportions of cells allocated to ICM were similar in blastocysts from albumin-supplemented $(0.37 \pm 0.01)$ and protein-free media $(0.36 \pm 0.02)$ and, in each case, exceeded the corresponding proportions for those from either SSA $(0.29 \pm 0.02 ; P<0.001)$ or SSB $(0.31 \pm 0.02$; $P<0.01$ versus SBSA; $P<0.05$ versus SPVA).

\section{Total number of cells and blastocyst diameters}

Among blastocysts produced in replicates five, nine and ten, cell proliferation was again greater after culture in albumin-supplemented medium (mean \pm SEM $=107 \pm 11$ ) than in all of the other formulations $(P<0.001)$, and none of these differed from the others (SSA $=73 \pm 9$; SSB = $69 \pm 6$; SPVA $=79 \pm 7)$. Thus, although the number of cells tended to be lower than those reported for replicates one to four inclusive, the relative impact of the different media was unchanged.

The most obvious difference between blastocysts from the defined and protein-supplemented cultures was that the former were less expanded (mean \pm SEM $=168 \pm 5 \mu \mathrm{m}$; $n=19$ ) than blastocysts produced in the presence of protein $(P<0.01)$. Corresponding zona pellucida-inclusive diameters of blastocysts produced in SSA, SSB and SBSA were $181 \pm 3 \mu \mathrm{m}(n=27), 188 \pm 5 \mu \mathrm{m}(n=28)$ and $186 \pm 5 \mu \mathrm{m}$ $(n=18)$, consistent with the overall evidence (Table 2$)$ that fewer were hatching by day $8(1 \%)$ than for serum-derived (SSA, 4\%; SSB, 5\%) and, more emphatically, albuminderived (18\%) blastocysts.

\section{De novo protein synthesis}

Incorporation of $\left[{ }^{3} \mathrm{H}\right]$ phenylalanine into PCA-precipitable protein (replicates six to ten) was similar, withinstage, for blastocysts generated in protein-supplemented and protein-free culture systems (Table 4). Only expanding blastocysts generated in the presence of serum B had inferior indices of protein synthesis compared with those produced in the presence of albumin. Mean ( \pm SEM) cumulative indices $\left(\log _{10}\right.$ d.p.m.) of $\left[{ }^{3} \mathrm{H}\right]$ phenylalanine incorporation were $3.10 \pm 0.05,2.98 \pm 0.05,3.29 \pm 0.04$ and $3.02 \pm 0.05$ for blastocysts produced in SSA, SSB, SBSA and SPVA, respectively.

\section{Discussion}

Amino acids, by virtue of their roles in protein synthesis, osmoregulation, nucleotide substrate provision and induction or control of gene expression, are among the factors most likely to influence preimplantation development, signalling and subsequent viability of mammalian embryos. Therefore, it is encouraging that, in the present study, amino acid utilization indices of blastocysts from a defined, protein-free system generally did not differ from those of blastocysts produced, albeit more efficiently, in albumin- or serum-supplemented systems.

Previous investigations have shown that bovine embryos produced in vivo or in vitro use most amino acids that are available to them. The significant and consistent exception is alanine, which invariably is released into the environment of the embryo (Lee and Fukui, 1996; Partridge and Leese, 1996; Jung et al., 1998; Donnay and Leese, 1999; Donnay et al., 1999). The same overall pattern with respect to amino acid flux was maintained in the present study, although the greatest legacy of blastocyst origin was that the magnitude of alanine release was almost halved among those generated in protein-free conditions. This finding may reflect a reluctance to relinquish any amino acid when, as demonstrated by Thompson et al. (1998), the protein complement of such embryos is already diminished. However, it is unlikely that the diminished release of alanine reflects increased retention as free amino acid in an unaltered form; rather, it is more likely to be used for protein synthesis or, perhaps, as a glucogenic precursor of pyruvate. The extent of alanine release from embryos produced in albumin-supplemented medium in the present study $\left(\right.$ mean $=9.5$ pmol per embryo $\left.\mathrm{h}^{-1}\right)$ is similar to that reported by Lee and Fukui (1996) and by Jung et al. (1998) for IVFderived bovine blastocysts produced in vitro in SOF medium supplemented with albumin and subsequently incubated for $10 \mathrm{~h}$ in conditions equivalent to those used in the present study. Partridge and Leese (1996) also recorded highly significant, albeit less marked, alanine release from 
Table 2. In vitro development of bovine embyos in serum supplemented (SSA, SSB), albumin supplemented (SBSA) and protein-free (SPVA) synthetic oviductal fluid media formulations

\begin{tabular}{|c|c|c|c|c|}
\hline Characteristic & SSA & SSB & SBSA & SPVA \\
\hline Number of zygotes & $87 \pm 6$ & $85 \pm 6$ & $89 \pm 6$ & $123 \pm 9$ \\
\hline Zygotes cleaved / total (\%) & $62 \pm 3^{e}$ & $63 \pm 2^{e}$ & $76 \pm 2^{f}$ & $73 \pm 2^{f}$ \\
\hline Day 7 blastocysts (\% of cleaved) & $26 \pm 4^{\mathrm{e}}$ & $24 \pm 3^{e}$ & $15 \pm 2^{\text {fg }}$ & $8 \pm 2^{\text {fh }}$ \\
\hline Days 7 and day 8 blastocysts (\% of cleaved) & $36 \pm 3^{\text {ae }}$ & $34 \pm 4^{\mathrm{e}}$ & $30 \pm 2^{\text {be }}$ & $15 \pm 2^{f}$ \\
\hline Grade 1 and 2 blastocysts (\% of cleaved) & $22 \pm 3^{e}$ & $23 \pm 3^{e}$ & $20 \pm 2^{\mathrm{e}}$ & $10 \pm 2^{f}$ \\
\hline Grade 1 and 2 blastocysts (\% of total) & $61 \pm 3$ & $66 \pm 5$ & $69 \pm 3$ & $60 \pm 4$ \\
\hline Hatching blastocysts (\% of grades 1 and 2 ) & $4 \pm 2^{c}$ & $5 \pm 2^{c}$ & $18 \pm 4^{d}$ & $1 \pm 1^{c}$ \\
\hline
\end{tabular}

Values are presented as mean \pm SEM from ten replicates.

Within rows, values with different superscripts differ as follows: a versus $b, P<0.05 ;$ c versus $d, P<0.01$; e versus f, $P<0.001 ; g$ versus $h, P<0.001$.

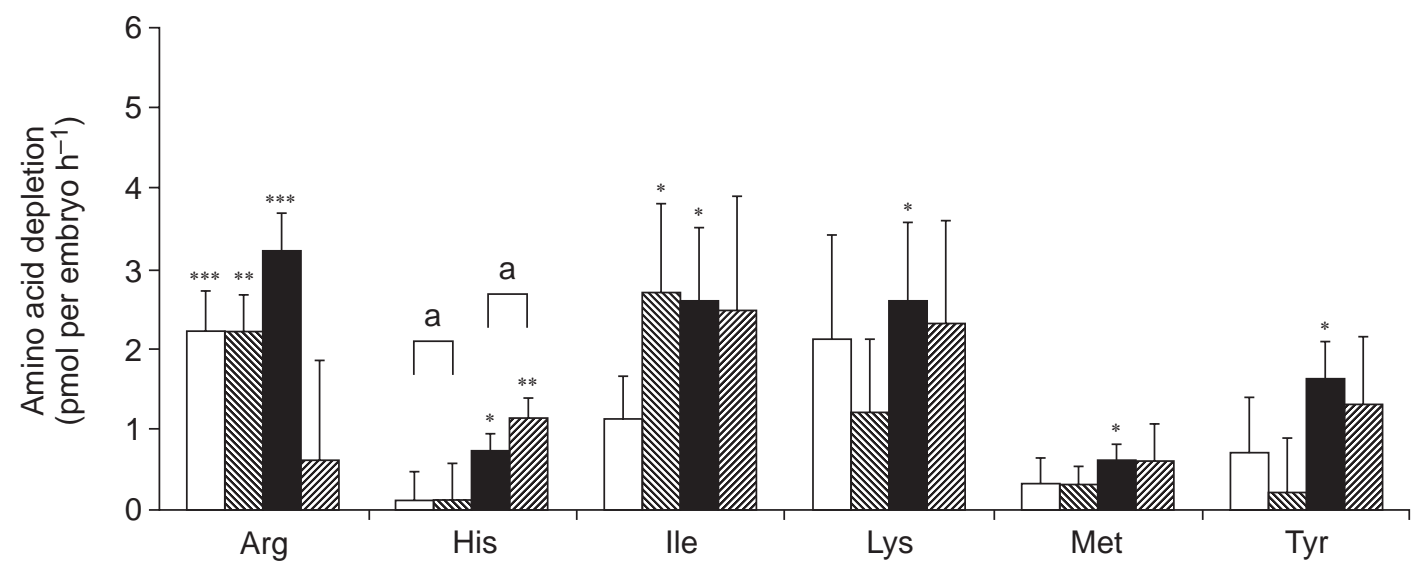

Fig. 2. Depletion of essential amino acids after $12 \mathrm{~h}$ of incubation (day 7.5 to day 8.0) of bovine blastocysts produced in vitro in the presence of serum (SSA, $\square ; \mathrm{SSB}, \mathbb{\mathbb { Q }}$ ) or albumin (SBSA, $\mathbf{\square}$ ) or in the absence of protein (SPVA, in protein-free 'test' medium (synthetic oviduct fluid, polyvinyl alcohol, essential amino acids and non-essential amino acids). Values are mean \pm SEM net depletion data $(n=8-10$ replicates) expressed in pmol per embryo $\mathrm{h}^{-1}$. Differences from 'control' (embryo-free) droplet values are denoted by asterisks ${ }^{*} P<0.05$, $\left.{ }^{* *} P<0.01,{ }^{* * *} P<0.001\right)$. Note that, in the case of histidine, presence or absence of serum significantly affected depletion rates $\left({ }^{\mathrm{a}} P<0.05\right)$.

both in vivo-derived blastocysts (approximately 3 pmol per embryo $\mathrm{h}^{-1}$ ) and blastocysts produced in vitro in albuminsupplemented SOF medium (approximately 4 pmol per embryo $\mathrm{h}^{-1}$ ). None of those studies reported amino acid flux in blastocysts produced in defined or serum-supplemented conditions.

Profiles for glycine, the single most abundant amino acid in the bovine oviduct and uterus (Elhassan et al., 2001), although consistently indicating net utilization rather than release, were significantly different from control droplet values only for blastocysts produced in the presence of serum A. Serine, which can be converted to provide glycine and the active carbon atoms for purine synthesis (Jozwik et al., 1999), was consumed in significant amounts by blastocysts produced in the presence of the same serum. In contrast, neither glycine nor serine was sought by blastocysts produced in the presence of serum B, arguably because the latter was a richer source of each. However, such a deduction was not always valid: for instance, despite being more abundant in serum B, both proline and isoleucine were avidly used by blastocysts grown in the presence of serum B but not serum A. Consequently, the present study indicates that amino acid profiles of illdefined exogenous proteins are poor predictors of the extent to which amino acid requirements of embryos are fulfilled by such supplements.

The amino acid most avidly used by all blastocysts in the present study, regardless of origin, was aspartate, and this is in agreement with earlier reports (Lee and Fukui, 1996; Partridge and Leese, 1996). However, uptake was lower among blastocysts produced in defined medium than among those from albumin-supplemented conditions. Blastocysts produced in the presence of albumin were more advanced, so it is plausible that this finding merely reflects increasing demand for aspartate as embryos develop (Partridge and Leese, 1996). Alternatively, the possibility that blastocysts produced in defined conditions have more limited uptake capabilities cannot be exluded. How- 
Table 3. Depletion indices for amino acids that were not influenced by prior embryo culture treatment and the concentrations of which, after $12 \mathrm{~h}$ incubation in the presence of embryos, did not differ significantly from those for 'control' (embryo-free) droplets

\begin{tabular}{|c|c|c|c|c|}
\hline \multirow[b]{3}{*}{ Amino acid } & SSA & SSB & SBSA & SPVA \\
\hline & \multicolumn{4}{|c|}{ Number of replicates } \\
\hline & 10 & 8 & 8 & 9 \\
\hline Asparagine & $0.8 \pm 0.6$ & $1.1 \pm 0.5$ & $0.4 \pm 0.5$ & $2.4 \pm 1.5$ \\
\hline Glutamine & $-2.0 \pm 2.6$ & $-0.6 \pm 3.1$ & $1.2 \pm 2.9$ & $0.3 \pm 6.9$ \\
\hline Leucine & $1.9 \pm 1.2$ & $1.3 \pm 0.9$ & $1.1 \pm 0.8$ & $2.3 \pm 1.6$ \\
\hline Phenylalanine & $2.0 \pm 1.9$ & $3.5 \pm 1.8$ & $1.3 \pm 0.6$ & $1.4 \pm 0.9$ \\
\hline Threonine & $0.3 \pm 1.3$ & $0.6 \pm 0.5$ & $1.4 \pm 0.9$ & $1.9 \pm 1.2$ \\
\hline Valine & $3.9 \pm 1.2$ & $1.1 \pm 0.8$ & $1.0 \pm 0.6$ & $2.6 \pm 1.3$ \\
\hline
\end{tabular}

Values are mean \pm SEM net depletion data ( $n=8-10$ replicates) expressed in pmoles per embryo $\mathrm{h}^{-1}$.

In vitro development of bovine embyos in serum supplemented (SSA, SSB), albumin supplemented (SBSA) and protein-free (SPVA) synthetic oviductal fluid media formulations

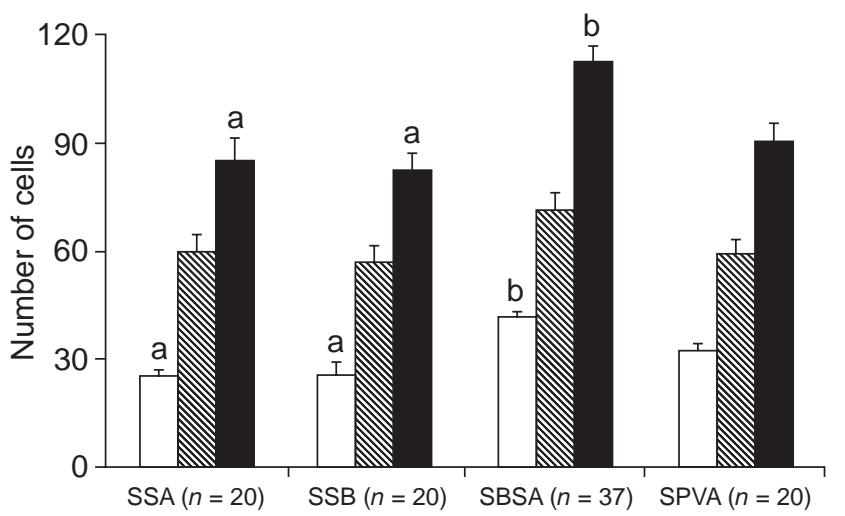

Fig. 3. Mean ( \pm SEM) inner cell mass (ICM, $\square)$, trophectoderm (TE, $\mathbb{N})$ and total number of cells $(\mathbf{\square})$ for bovine blastocysts (replicates one to four) produced in the presence of serum (SSA; SSB) or albumin (SBSA) or in the absence of protein (SPVA). Cells were identified on the basis of phenotype, using a differential staining procedure, which discriminated between cells that produced interferon $\tau$ (IFN- $\tau$ ) (TE cells) and those which did not (ICM cells). Within each cell category, all significant differences are indicated as follows: a versus b $(P<0.05)$.

ever, a comparison of SBSA- and SPVA-derived blastocysts, showed that no other amino acid index, except that of alanine, was found to differ significantly. This finding does not support any major disruption of amino acid profiles in the latter population although, whether expressed in absolute or comparative terms, amino acid flux data must be interpreted with caution. For example, the question as to whether the consistently similar relative demand for amino acids is indicative of analogous intracellular amino acid precursor pools, and hence comparable capacities for de novo protein synthesis, is a matter for further investigation. However, as demonstrated in a study by Kuran et al. (2001), de novo synthesis of acid-precipitable protein in the present study was comparable, within-stage, for blastocysts pro- duced in either albumin-supplemented or protein-free conditions. Thompson et al. (1998) reported similar findings even though, as in both the present and previous studies, blastocyst diameters were greater among their albuminderived embryos.

In contrast to the non-significant net uptake of histidine by serum-derived embryos, this essential glucogenic $\mathrm{C}_{5}$ amino acid was avidly used by blastocysts produced in either albumin-dependent $(P<0.05)$ or protein-free $(P<0.01)$ conditions. Although blastocysts generated in the presence of either serum would have had access to various forms of this amino acid, demand for histidine among blastocysts produced in the defined system, and to a lesser extent among those provided with albumin, may reflect a tendency to compensate for an earlier lack of this particular amino acid.

Demand for another glucogenic $C_{5}$ amino acid, arginine, an effector of improved nutrient supply and increased protein synthesis in mammalian embryos (Van Winkle, 2001), was significant among blastocysts from the three protein-supplemented systems. Lee and Fukui (1996) also reported significant arginine uptake by blastocysts produced in the presence of albumin, but Partridge and Leese (1996) did not. Therefore, access to albumin does not necessarily equate with adequate or optimal provision of required amino acids, a fact frequently underlined by the beneficial effects of amino acid addition to media containing supplementary albumin (Takahashi and First, 1992; Gardner et al., 1994; Steeves and Gardner, 1999). In the present study, variable but low arginine uptake was a feature of blastocysts from protein-free medium but reasons for this are not clear. One possibility, applicable to other amino acids too, is that endogenous protein degradation contributed to arginine requirements. Although not sustainable, such a process may be more prevalent among blastocysts from defined conditions (Thompson et al., 1998) and ought to provide a near-ideal amino acid supply in the short term.

Although our PVA-supplemented formulation yielded 
Table 4. Indices of de novo synthesis of protein by bovine blastocysts produced in vitro in the presence of serum (SSA; SSB) or albumin (SBSA) or in the absence of protein (SPVA)

\begin{tabular}{lcccc}
\hline Blastocyst categories & SSA & SSB & SBSA & SPVA \\
\hline Early to mid-blastocyst $(n)$ & $2.6 \pm 0.21$ & $2.8 \pm 0.03$ & $3.2 \pm 0.06$ & $3.0 \pm 0.06$ \\
& $(6)$ & $(3)$ & $(3)$ & $(8)$ \\
Expanding blastocyst $(n)$ & $3.1 \pm 0.06$ & $2.9 \pm 0.09^{\mathrm{a}}$ & $3.3 \pm 0.08^{\mathrm{b}}$ & $3.0 \pm 0.10$ \\
& $(21)$ & $(12)$ & $(8)$ & $(9)$ \\
Expanded to hatched & $3.2 \pm 0.07$ & $3.1 \pm 0.07$ & $3.3 \pm 0.05$ & $3.2 \pm 0.06$ \\
blastocyst $(n)$ & $(23)$ & $(17)$ & $(23)$ & $(5)$ \\
\hline
\end{tabular}

Results are expressed as mean ( \pm SEM) values for $\left[{ }^{3} \mathrm{H}\right]$ phenylalanine incorporation $\left(\log _{10}\right.$ d.p.m.) into perchloric acidprecipitable protein.

Within rows, values with different superscripts are significantly different $(P<0.01)$.

fewer blastocysts, those that were produced showed analogous differentiation, based on trophectoderm-specific IFN- $\tau$ gene expression, compared with that of blastocysts generated in the presence of protein. Use of this 'phenotypic' assay avoided the limitations and errors inherent in alternative 'inside-outside' immunoassay procedures which presuppose and depend on 'robust' cell-cell cohesion. The assay data from the present study are consistent with the findings reported by Wrenzycki et al. (1999) that production of bovine embryos in chemically defined culture environments does not compromise IFN- $\tau$ gene expression. In view of the critical role played by this trophectoderm-specific protein in ensuring maternal recognition and establishment of pregnancy, this may be very important.

Exclusion of essential amino acids from the defined medium formulation in the present study was guided by the outcome of earlier work in our laboratory, which indicated that blastocyst production was virtually nullified by their inclusion at a standard rate (McEvoy et al., 2000c). However, rather than resorting to their complete exclusion, alternative 'non-standard' inclusion rates (see, for example, Liu and Foote, 1995) may help to safeguard development by virtue of the influence of essential amino acids on expression of stress-responsive and other genes in preimplantation embryos, in particular those that contain amino acid response elements. Notable among these are CCAAT/enhancer binding protein homologous protein $(C H O P)$ genes, the asparagine synthetase $(A S)$ gene and the insulin-like growth factor binding protein-I (IGFBP-I) gene (Fafournoux et al., 2000). CHOP (also known as gadd153) is ubiquitous and, in collaborative studies led by W. D. Rees, we have demonstrated that its expression in bovine embryos is altered in vitro in response to stress (Fontanier-Razzaq et al., 2001). $\mathrm{CHOP}$ gene expression precedes induction of apoptosis in embryonic cells (Fontanier-Razzaq et al., 1999) and is thought to be involved in ensuring the elimination of aberrant or damaged cells. Consequently, serum, which has been shown to restrain $\mathrm{CHOP}$ gene expression (Kashima et al., 1995), may serve only to perpetuate developmental errors.

When embryos are produced in vitro in the absence of exogenous proteins, they are denied the facility to endocytose polypeptides in a manner known to occur in vitro
(Pemble and Kaye, 1976; Dunglison and Kaye, 1995; Thompson et al., 1998) and likely to be availed of in vivo. Whether such deprivation is undesirable is a matter of ongoing debate, and opinions are divided on the necessity to include protein in vitro. Normal offspring have been generated after in vitro culture of rodent, ruminant and pig embryos in protein-free conditions (Bavister, 1995; Keskintepe et al., 1995; Holm et al., 1999; McEvoy et al., 2000c; Hernandez-Fonseca et al., 2002; Yoshioka et al., 2002), but there is ample evidence, including that from the present study, to indicate that embryos produced in such conditions are, in the short term, functionally modified. A crucial question, therefore, is whether such functional modification is ultimately benign or inevitably harmful; thus far, the former remains a reasonable possibility. Moreover, in countries where the alternative option (that is, protein provision) is neither ideal nor hazard-free, decision-making ought to be governed by the relative rather than absolute merits of protein-free in vitro embryo production strategies.

In conclusion, the present study contributes to the ongoing investigations and debates concerning the options available to embryologists, and consequences of their decisions, in relation to in vitro production of mammalian embryos, especially wherever biohazard-free protein supplements are not readily available. The results from the present study demonstrate that depriving preimplantation bovine embryos of exogenous protein throughout the first week after fertilization resulted in halving of blastocyst yields in the absence of essential amino acids. However, there was encouraging evidence that blastocysts generated from protein-deprived embryos were developmentally competent in terms of amino acid utilization, cell differentiation and protein synthesis.

This project was funded by the Ministry of Agriculture Fisheries and Food (now the Department for Environment, Food and Rural Affairs). The Scottish Agricultural College receives financial support from the Scottish Executive Environment and Rural Affairs Department. The authors thank M. Stojkovic (University of Munich) for the gift of antibody against IFN- $\tau$, and V. Buchan (RRI), M. E. Staines, G. J. McCallum, A. G. Onal and A. Reis (SAC) for their expert assistance. M. Kuran thanks Ondokuz Mayis University of Turkey for leave of absence. 


\section{References}

Abe H, Otoi T, Tachikawa S, Yamashita S, Satoh T and Hoshi H (1999a) Fine structure of bovine morulae and blastocysts in vivo and in vitro. Anatomy and Embryology (Berlin) 199 519-527

Abe H, Yamashita S, Itoh T, Satoh T and Hoshi H (1999b) Ultrastructure of bovine embryos developed from in vitro-matured and -fertilized oocytes: comparative morphological evaluation of embryos cultured either in serum-free medium or in serum-supplemented medium Molecular Reproduction and Development 53 325-335

Bavister BD (1995) Culture of preimplantation embryos: facts and artifacts Human Reproduction Update 191-148

Byrne AT, Southgate J, Brison DR and Leese HJ (1999) Analysis of apoptosis in the preimplantation bovine embryo using TUNEL Journal of Reproduction and Fertility 117 97-105

Carolan C, McEvoy TG, Gebbie FE, Sinclair KD, Robinson JJ and Broadbent PJ (1997) Steer sera from different nutritional backgrounds alter ammonia and progesterone concentrations in a bovine granulosa cell culture system Journal of Reproduction and Fertility Abstract Series 19 126

Donnay I and Leese HJ (1999) Embryo metabolism during the expansion of the bovine blastocyst Molecular Reproduction and Development $\mathbf{5 3}$ $171-178$

Donnay I, Partridge RJ and Leese HJ (1999) Can embryo metabolism be used for selecting bovine embryos before transfer? Reproduction, Nutrition and Development 39 523-533

Dunglison GF and Kaye PL (1995) Endocytosis in mouse blastocysts: characterization and quantification of the fluid phase component Molecular Reproduction and Development 41 225-231

Eckert J, Pugh PA, Thompson JG, Niemann H and Tervit HR (1998) Exogenous protein affects developmental competence and metabolic activity of bovine pre-implantation embryos in vitro. Reproduction, Fertility and Development 10 327-332

Elhassan YM, Wu G, Leanez AC, Tasca RJ, Watson AJ and Westhusin ME (2001) Amino acid concentrations in fluids from the bovine oviduct and uterus and in KSOM-based culture media Theriogenology $\mathbf{5 5}$ 1907-1918

Fafournoux P, Bruhat A and Jousse C (2000) Amino acid regulation of gene expression Biochemical Journal 351 1-12

Fontanier-Razzaq NC, Hay SM and Rees WD (1999) Upregulation of CHOP-10 (gadd153) expression in the mouse blastocyst as a response to stress Molecular Reproduction and Development 54 326-332

Fontanier-Razzaq NC, McEvoy TG, Robinson JJ and Rees WD (2001) DNA damaging agents increase gadd153 (CHOP-10) messenger RNA levels in bovine preimplantation embryos cultured in vitro. Biology of Reproduction 64 1386-1391

Gardner DK (1999) Development of serum-free culture systems for the ruminant embryo and subsequent assessment of embryo viability Journal of Reproduction and Fertility Supplement 54 461-475

Gardner DK, Lane M, Spitzer A and Batt PA (1994) Enhanced rates of cleavage and development for sheep zygotes cultured to the blastocyst stage in vitro in the absence of serum and somatic cells: amino acids, vitamins and culturing embryos in groups stimulate development Biology of Reproduction $\mathbf{5 0}$ 390-400

Guerin B, Nibart M, Marquant-Le Guienne B and Humblot P (1997) Sanitary risks related to embryo transfer in domestic species Theriogenology 47 33-42

Heinrikson RL and Meredith SC (1984) Amino acid analysis by reversephase high-performance liquid chromatography: precolumn derivatization with phenylisothiocyanate Analytical Biochemistry 136 65-74

Hernandez-Fonseca HJ, Sirisathien S, Bosch P, Cho HS, Lott JD, Hawkins LL, Hollett RB, Coley SL and Brackett BG (2002) Offspring resulting from direct transfer of cryopreserved bovine embryos produced in vitro in chemically defined media Animal Reproduction Science 69 151-158

Holm P and Callesen H (1998) In vivo versus in vitro produced bovine ova: similarities and differences relevant for practical application Proceedings of the 14th Scientific Meeting of the European Embryo Transfer Association (AETE), 11-12 September; Venice, Italy. pp 65-79

Holm P, Booth PJ, Schmidt MH, Greve T and Callesen H (1999) High bovine blastocyst development in a static in vitro production system using SOFaa medium supplemented with sodium citrate and myoinositol with or without serum-proteins Theriogenology 52 683-700

Jozwik M, Teng C, Meschia G and Battaglia FC (1999) Contribution of branched-chain amino acids to uteroplacental ammonia production in sheep Biology of Reproduction 61 792-796

Jung YG, Sakata T, Lee ES and Fukui Y (1998) Amino acid metabolism of bovine blastocysts derived from parthenogenetically activated or in vitro fertilized oocytes Reproduction, Fertility and Development 10 279-287

Kashima N, Ueohzono T, Fornace AJ and Ide T (1995) Induction of gadd153 gene in G0-specific ts mutant cells at nonpermissive temperature Experimental Cell Research 217 324-328

Keskintepe L, Burnley CA and Brackett BG (1995) Production of viable bovine blastocysts in defined in vitro conditions Biology of Reproduction 52 1410-1417

Krisher RL, Lane M and Bavister BD (1999) Developmental competence and metabolism of bovine embryos cultured in semi-defined and defined culture media Biology of Reproduction 60 1345-1352

Kuran M, Onal AG, McCallum GJ, Staines ME, Stojkovic M and McEvoy TG (1999) Inner cell mass (ICM) and trophectoderm (TE) cell numbers in bovine embryos produced in vivo or in vitro. Proceedings of the 25th Meeting of Turkish Physiological Society Abstract S27

Kuran M, Robinson JJ, Staines ME and McEvoy TG (2001) Development and de novo protein synthetic activity of bovine embryos produced in vitro in different culture systems Theriogenology 55 593-606

Lee E-S and Fukui Y (1996) Synergistic effects of alanine and glycine on bovine embryos cultured in a chemically defined medium and amino acid uptake by in vitro produced bovine morulae and blastocysts Biology of Reproduction 55 1383-1389

Leese HJ, Donnay I and Thompson JG (1998) Human assisted conception: a cautionary tale. Lessons from domestic animals Human Reproduction 13 Supplement 4 184-202

Lindner GM and Wright RW, Jr (1983) Bovine embryo morphology and evaluation Theriogenology 20 407-416

Liu Z and Foote RH (1995) Effects of amino acids on the development of in vitro matured/in vitro fertilization bovine embryos in a simple proteinfree medium Human Reproduction 10 2985-2991

Lu KH, Gordon I, Gallagher M and McGovern H (1987) Pregnancy established in cattle by transfer of embryos derived from in vitro fertilisation of oocytes matured in vitro. Veterinary Record 121 259-260

McEvoy TG and Sreenan JM (1990) Effect of embryo quality and stage of development on the survival of zona pellucida-free cattle demi-embryos Theriogenology 33 1245-1253

McEvoy TG, Robinson IJ, Aitken RP, Findlay PA, Palmer RM and Robertson IS (1995) Dietary-induced suppression of pre-ovulatory progesterone concentrations in superovulated ewes impairs the subsequent in vivo and in vitro development of their ova Animal Reproduction Science 39 89-107

McEvoy TG, Robinson JJ, Aitken RP, Findlay PA and Robertson IS (1997) Dietary excesses of urea influence the viability and metabolism of preimplantation sheep embryos and may affect foetal growth among survivors Animal Reproduction Science 47 71-90

McEvoy TG, Sinclair KD, Young LE, Wilmut I and Robinson JJ (2000a) Large offspring syndrome and other consequences of ruminant embryo culture in vitro: relevance to blastocyst culture in human ART Human Fertility 3 238-246

McEvoy TG, Kuran M, Brown D, Buchan V, McCallum GJ, Wilmut I, Sinclair KD and Robinson JJ (2000b) Amino acid uptake by bovine embryos produced in different culture systems Theriogenology 53300

McEvoy TG, Staines ME, McCallum GJ and Kuran M (2000c) Bovine blastocyst production in defined medium is influenced by amino acid supplementation Journal of Reproduction and Fertility Abstract Series $\mathbf{2 5}$ 42

Natale DR, Westhusin ME and Watson AJ (1998) Characterization of differentially expressed mRNAs in bovine pre-attachment embryos cultured in defined and serum-supplemented/co-culture systems Theriogenology 49188

Niemann H and Wrenzycki C (2000) Alterations of expression of developmentally important genes in preimplantation bovine embryos by 
in vitro culture conditions: implications for subsequent development Theriogenology 53 21-34

Parrish JJ, Susko-Parrish JL, Leibfried-Rutledge ML, Critser ES, Eyestone WH and First NL (1986) Bovine in vitro fertilization with frozen-thawed semen Theriogenology 25 591-600

Partridge RJ and Leese HJ (1996) Consumption of amino acids by bovine preimplantation embryos Reproduction, Fertility and Development 8 945-950

Pemble LB and Kaye PL (1976) Whole protein uptake and metabolism by mouse blastocysts Journal of Reproduction and Fertility 78 149-157

Rieger D, Grisart B, Semple E, Van Langendonckt A, Betteridge KJ and Dessy F (1995) Comparison of the effects of oviductal cell co-culture and oviductal cell-conditioned medium on the development and metabolic activity of cattle embryos Journal of Reproduction and Fertility 105 91-98

Sinclair KD, McEvoy TG, Maxfield EK, Maltin CA, Young LE, Wilmut I, Broadbent PJ and Robinson JJ (1999) Aberrant foetal growth and development after in vitro culture of sheep zygotes Journal of Reproduction and Fertility 116 176-186

Steeves TE and Gardner DK (1999) Temporal and differential effects of amino acids on bovine embryo development in culture Biology of Reproduction 61 731-740

Stojkovic M, Buttner M, Zakhartchenko V, Brem G and Wolf E (1998) A reliable procedure for differential staining of in vitro produced bovine blastocysts: comparison of tissue culture medium 199 and Menezo's B2 medium Animal Reproduction Science 50 1-9

Takahashi Y and First NL (1992) In vitro development of bovine one-cell embryos: influence of glucose, lactate, pyruvate, amino acids and vitamins Theriogenology 37 963-978

Tervit HR, Whittingham DG and Rowson LEA (1972) Successful culture in vitro of sheep and cattle ova Journal of Reproduction and Fertility $\mathbf{3 0}$ 493-497

Thompson JG (1997) Comparison between in vivo-derived and in vitroproduced pre-elongation embryos from domestic ruminants Reproduction, Fertility and Development 9 341-354

Thompson JG (2000) In vitro culture and embryo metabolism of cattle and sheep embryos: a decade of achievement Animal Reproduction Science 60-61 263-275

Thompson JG, Sherman ANM, Allen NW, McGowan LT and Tervit HR (1998) Total protein content and protein synthesis within pre-elongation stage bovine embryos Molecular Reproduction and Development 50 139-145

Van Soom A, Boerjan M, Ysebaert M and de Kruif A (1996) Cell allocation to the inner cell mass and the trophectoderm in bovine embryos cultured in two different media Molecular Reproduction and Development 45 171-182

Van Winkle LJ (2001) Amino acid transport regulation and early embryo development Biology of Reproduction 64 1-12

Wrenzycki C, Herrmann D, Carnwath JW and Niemann H (1996) Expression of the gap junction gene connexin43 (Cx43) in preimplantation bovine embryos derived in vitro or in vivo. Journal of Reproduction and Fertility 108 17-24

Wrenzycki C, Herrmann D, Carnwath JW and Niemann H (1999) Alterations in the relative abundance of gene transcripts in preimplantation bovine embryos cultured in medium supplemented with either serum or PVA Molecular Reproduction and Development 53 8-18

Wrenzycki C, Herrmann D, Keskintepe L, Martins A, Jr, Sirisathien S, Brackett B and Niemann H (2001) Effects of culture system and protein supplementation on mRNA expression in pre-implantation bovine embryos Human Reproduction 16 893-901

Yoshioka K, Suzuki C, Tanaka A, Anas IM and Iwamura S (2002) Birth of piglets derived from porcine zygotes cultured in a chemically defined medium Biology of Reproduction 66 112-119

Young LE, Fernandes K, McEvoy TG et al. (2001) Epigenetic change in $I G F 2 R$ is associated with fetal overgrowth after sheep embryo culture Nature Genetics 27 153-154

Received 10 August 2001.

First decision 23 October 2001.

Manuscript resubmitted 4 March 2002.

Accepted 4 March 2002. 